\begin{tabular}{|l|l|l||}
\hline \multicolumn{2}{|c|}{ PublisherInfo } \\
\hline \hline PublisherName & $:$ & BioMed Central \\
\hline \hline PublisherLocation & $:$ & London \\
\hline \hline PublisherImprintName & $:$ & BioMed Central \\
\hline \hline
\end{tabular}

\title{
Tales of PU
}

\begin{tabular}{|l|l|l||}
\hline \multicolumn{2}{|c|}{ ArticleInfo } \\
\hline \hline ArticleID & $:$ & 3961 \\
\hline \hline ArticleDOI & $:$ & $10.1186 /$ gb-spotlight-20010119-01 \\
\hline \hline ArticleCitationID & $:$ & spotlight-20010119-01 \\
\hline \hline ArticleSequenceNumber & $:$ & 32 \\
\hline \hline ArticleCategory & $:$ & Research news \\
\hline \hline ArticleFirstPage & $:$ & 1 \\
\hline \hline ArticleLastPage & $:$ & 2 \\
\hline \hline & & RegistrationDate : 2001-01-19 \\
ArticleHistory & $:$ & OnlineDate \\
\hline \hline ArticleCopyright & $:$ & BioMed Central Ltd2001 \\
\hline \hline ArticleGrants & $:$ & \\
\hline \hline ArticleContext & $:$ & 130592211 \\
\hline \hline
\end{tabular}




\section{Jonathan B Weitzman}

Email: jonathanweitzman@hotmail.com

Members of the PU.1/Spi family of Ets-type transcription factors play key roles in mammalian hematopoiesis and lymphoid development. Lymphocytes are found in jawed vertebrates, including cartilaginous fish, but not in jawless vertebrates or invertebrates. In the January 16 Proceedings of the National Academy of Science Anderson et al. identified three PU.1 members in the cartilaginous fish Raja eglanteria (skate)(Proc Natl Acad Sci USA 2001, 98:553-558). Phylogenetic analysis established that one of the skate sequences is the ortholog of PU.1, one the ortholog of related Spi-C, and the third a divergent Spi-D gene. The skate PU.1 genes are expressed specifically in hematopoietic tissues. The strong conservation between skate and mammalian PU.1 members underscores their critical role in the development of the immune system.

\section{References}

1. Role of PU.1 in hematopoiesis.

2. Fishbase, [http://www.fishbase.org]

3. Proceedings of the National Academy of Science, [http://www.pnas.org]

4. Species Summary for Raja eglanteria, [http://www.fishbase.org/Summary/ SpeciesSummary.cfm?genusname=Raja\&speciesname=eglanteria $]$ 